\title{
Psykisk helse i Helse- og levekårsundersøkelsen i 1998 II. Geografiske forskjeller
}

\author{
Odd Steffen Dalgard, Marit Rognerud og Bjørn Heine Strand \\ Nasjonalt folkehelseinstitutt \\ Korrespondanse: Odd Steffen Dalgard, Nasjonalt folkehelseinstitutt, Postboks 4404 Nydalen, 0403 Oslo \\ E-post: o.s.dalgard@samfunnsmed.uio.no
}

\begin{abstract}
SAMMENDRAG
I en landsomfattende befolkningsundersøkelse finner en at hyppigheten av psykiske plager, målt ved HSCL25 , varierer signifikant mellom ulike geografiske områder, både for menn og kvinner. For begge kjønn finner vi den største hyppighet av psykiske plager i Oslo, men dette er noe mer uttalt for menn enn kvinner. For kvinner peker også Hedmark/Oppland og Nord-Norge seg negativt ut, mens Østlandet og Akershus kommer relativt dårlig ut blant menn. For begge kjønn finnes den laveste hyppighet av psykiske plager på Vestlandet (for kvinner inklusive Bergen). Når det gjelder de sosiodemografiske variable, viser også disse interessante geografiske forskjeller. Andel ikke gifte er størst i Oslo, spesielt for kvinner, mens andel med lite utdannelse er størst i Hedmark/Oppland og i Nord-Norge, igjen for begge kjønn. Inntektsnivået viser et mer uklart mønster, der Oslo kommer best ut blant kvinnene, mens dette ikke gjelder mennene. Når det gjelder sosialt nettverk kommer Oslo forholdsvis godt ut, mens det på Vestlandet og Stavanger er forholdsvis mange som oppgir at de ikke har noen fortrolige venner utenom familien. Dette gjelder begge kjønn. Forbruket av alkohol er klart størst i byene for begge kjønn. Selv om det er en viss geografisk samvariasjon mellom andel ikkegifte, lavt utdannelsesnivå og psykiske plager i materialet, forsvinner ikke de geografiske forskjeller når det kontrolleres statistisk for de sosiodemografiske variable. Data peker imidlertid i retning av at store sosiale ulikheter innen Oslo bidrar til å forklare den relativt store hyppighet av psykiske plager i Norges største by.
\end{abstract}

\section{Dalgard OS, Rognerud M, Strand BH. Mental health in Norway 1998. II. Geographical differences. Nor J Epidemiol 2002; 12 (3): 249-256.}

\section{ENGLISH SUMMARY}

In an nationwide survey from Norway where psychological distress was measured by HSCL-25, there were significant geographical differences. The highest prevalence of distress was found in Oslo for both genders, especially for men. Again for both genders, the lowest prevalence was found in the western part of Norway. For women also the the inner eastern part and the northern part of Norway had a relatively high prevalence of distress, whereas for men the county around Oslo had high figures. With respect to sociodemographic variables, Oslo had the highest proportion of not-married, especially not-married women, whereas the level of education was lowest in the inner eastern and northern part of Norway. The level of alcohol consumption was highest in the urban areas. Even if there was some geographical co-variation between the proportion of notmarried, low education and distress, the geographical differences were not explained away when controlling for the socio-demographic variables in logistic regression analysis. The data, however, fit the hypothesis that social unequalities contributes to explain the higher rate of distress in the biggest city, Oslo.

\section{INNLEDNING}

Den foreliggende artikkel er den første som med utgangspunkt $\mathrm{i}$ en landsomfattende befolkningsundersøkelse beskriver fordelingen av lettere psykiske lidelser og plager i ulike deler av Norge. Tidligere undersøkelser har sammenliknet ulike geografiske områder, men de omfatter ikke hele landet.

Når det gjelder alvorlige sinnslidelser, finnes det helt tilbake til midten av det 19. århundrede publiserte oversikter over fordelingen i ulike deler av landet, basert på opplysninger fra ulike hold, blant annet prester og lærere. Således beskriver Dahl i 1859 at det finnes flest med "ervervet sinnssykdoms" i de indre dalfører på Østlandet, Sørlandet og Finnmark, mens Vestlandsfylkene kommer best ut (1).

\section{By/land}

I en intervju-undersøkelse fra bydelen Søndre Nordstrand i Oslo og fire kommuner i Lofoten (2) fant en ingen statistisk signifikant forskjell i psykiske plager mellom Oslo og Nord Norge. Psykiske plager var da målt ved HSCL-25, på samme måte som i den foreliggende undersøkelse. I tolkningen av disse funn må en ta hensyn til at Søndre Nordstrand i stor utstrekning er en ny drabantby, og at prevalenstallene her antakelig ligger noe over gjennomsnittet for Oslo. Dette skulle tilsi at hyppigheten av psykiske plager snarere 
er noe høyere i Lofoten enn i Oslo.

I en fersk befolkningsundersøkelse fra Oslo (HUBRO-undersøkelsen), der psykisk helse ble målt ved hjelp av en kortversjon av HSCL-25 (HSCL-10), var hyppigheten av psykiske plager betydelig høyere for alle aldersgrupper i Oslo sammenliknet med NordTrøndelag. Dette gjaldt både menn og kvinner (3).

I en intervju-undersøkelse fra Oslo og Sogn og Fjordane (4), også beskrevet i dette temanummeret av Norsk Epidemiologi, er det rapportert en betydelig høyere prevalens av psykiatriske lidelser, og spesielt av personlighetsforstyrrelser, i Oslo enn på Vestlandet. Psykiske lidelser er da målt ved det standardiserte kliniske intervju CIDI (5).

Som ledd i en større internasjonal undersøkelse, der en har sammenliknet prevalensen av depresjon i 5 europeiske byer (Oslo, Turku, Liverpool, Dublin og Santander) og nærliggende landdistrikter, fant en for Norges vedkommende ingen signifikant forskjell mellom Oslo og landdistriktet, Rakkestad (6). Depresjon var da målt gjennom en to-trinns undersøkelse: først en postal screening med BDI, og deretter intervjuing med det standardiserte intervju SCAN. Når det gjelder ungdom, fant Lavik betydelig mer atferdsforstyrrelser i Oslo enn i Østerdalen, noe som særlig gjaldt gutter (7).

\section{Landkommuner}

Det finnes flere undersøkelser fra Norge der en sammenlikner ulike kommuner med hensyn til psykisk helse, men der ikke Oslo eller noen andre større byer inngår. Noen av disse undersøkelsene faller innenfor betegnelsen helseprofiler i lokalsamfunn eller kommunediagnoser (8). Her finnes til dels interessante forskjeller, som passer med at lokalsamfunn med sviktende sosial integrasjon har en øket hyppighet av psykiske plager, målt med HSCL-25 gjennom et postalt spørreskjema. Et interessant funn er at særlig eldre menn $i$ et industri-tettsted som har vært gjennom en nedbygging av stedets hjørnestensbedrift, har en øket hyppighet av psykiske plager sammenliknet med de øvrige kommuner, mens noe eldre kvinner $i$ et kystsamfunn der det har vært nedbygging av fiskeindustrien også har mye psykiske plager (9). En fellesnevner for problemene i disse kommuner synes å være et sviktende arbeidsmarked, det ene sted for menn, det andre for kvinner. Ved sammenlikning av ulike landkommuner i Nordland fylke, fant Sørensen små forskjeller, igjen målt med HSCL-25 (10). Derimot hadde han tidligere funnet en signifikant øket hyppighet av psykiske plager i en typisk pendlerkommune sammenliknet med en stabil jordbrukskommune, begge på Østlandet (11).

\section{Oslo}

Det er påvist betydelige forskjeller med hensyn til psykiske helseproblemer innen Oslo. Således fant Dalgard i 1978 størst hyppighet av problemer i en ny drabantby, lavest hyppighet $\mathrm{i}$ etablerte villastrøk, mens den indre del av byen og en eldre drabantby kom i en mellomstilling (12). Psykisk helse var da målt gjennom et strukturert intervju med fokus på angst, depresjon og somatisering. Forskjellene kunne ikke forklares ved forskjeller i sosioøkonomisk status eller andre demografiske variable, og syntes å henge sammen med mangelfull sosial intergrasjon, svakt sosialt nettverk og mange livsbelastninger, ikke minst økonomiske, i den nye drabantbyen. Senere har Kringlen et al i sin tidligere omtalte befolkningsundersøkelse fra Oslo og Sogn og Fjordane funnet en øket hyppighet av sinnslidelser i de indre bydeler av Oslo. I HUBRO-undersøkelsen fant en både for menn og kvinner stigende hyppighet av psykiske plager i rekkefølgen "ytre vest", "indre vest", ytre øst" og "indre øst" (3). For kvinner var forskjellen størst for aldersgruppen 59-60 år, i det $29,1 \%$ av disse kvinnene i "indre øst", og bare 10,3\% i "indre vest", anga psykisk plager. For menn var forskjellene størst i aldersgruppene $40+45$ år, med 20,9\% med psykiske plager i "indre øst" og 10,8\% i "ytre vest". Konklusjonen på undersøkelsene fra Oslo blir da at det er større forskjeller med hensyn til psykiske plager innen byen, enn det en vanligvis finner mellom ulike kommuner.

\section{Utenlandske undersokelser}

\section{By/land}

Dohrenwend har sammenfattet resultatene fra 9 undersøkelser fra ulike deler av verden der en har sammenliknet hyppigheten av psykiske lidelser mellom by og land (13). Selv om metodene har variert mellom de ulike undersøkelser, har det likevel vært mulig å foreta sammenlikninger innen hver enkelt undersøkelse når det gjelder den totale forekomst av behandlede og ubehandlede tilfelle av psykiatrisk sykdom. Tendensen gikk klart i retning av størst psykiatrisk morbiditet i byene, i det dette var tilfelle i 7 av de 9 undersøkelser. Når en trakk inn sosial klasse i undersøkelsene, var det en klar tendens i retning av øket psykiatrisk morbiditet blant de fra laveste sosiale klasse $\mathrm{i}$ byene, mens det $\mathrm{i}$ landdistriktene var mindre forskjell knyttet til sosial klasse.

\section{Landkommuner}

Den mest kjente undersøkelsen innen dette felt er Stirling Country undersøkelsen fra Nova Scotia i Canada (14). Psykisk helse var da målt med et omfattende spørreskjema, med særlig vekt på angst, depresjon og somatisering. En fant størst hyppighet av psykiske lidelser i lokalsamfunn som var preget av sosial desintegrasjon, der det som følge av sviktende næringsliv, manglende lokalt lederskap, betydelig utflytting og uklar sammenblanding av ulike kulturelle og religiøse tradisjoner, hadde skjedd en delvis oppløsning av lokalsamfunnet, med svekkelse av sosiale nettverk og sosial interaksjon, og utvikling av pessimisme og manglende tro på fremtiden.

\section{Storbyer}

Flere undersøkelser har vist en tendens til opphopning av psykiske lidelser i de sentrale, og sosialt depriverte bydeler. Den mest kjente undersøkelsen i så måte er Faris \& Dunhams undersøkelse fra Chicago (15), som 
var basert på hospitaliserte psykoser. Spesielt når det gjaldt schizofreni, var hyppigheten størst i de sentrale bydeler, mens dette ikke var tilfelle for maniskdepressiv psykose.

Målsettingen for den aktuelle undersøkelse er å sammenlikne forekomsten (prevalensen) av lettere psykiske lidelser og plager i ulike deler av landet, og undersøke i hvor stor utstrekning eventuelle forskjeller kan forklares gjennom fordelingen av sosiodemografiske og psykososiale variable.

\section{MATERIALE OG METODE}

\section{Populasjon og utvalg}

Undersøkelsen er basert på det samme materiale som beskrevet av Rognerud et al ovenfor (16), nemlig Statistisk Sentralbyrås helseundersøkelse i 1998, og den omfatter i stor utstrekning de samme variable. Forskjellen er at en i denne undersøkelsen trekker inn bosted som den sentrale variabel. Når det gjelder utvalg og inndeling av de felles variable, skal det her bare gis en summarisk oversikt. For øvrig henvises til Rognerud et al (16) når det gjelder detaljer.

I utgangspunktet ble et landsomfattende utvalg på 10000 personer over 15 år trukket ut til å delta $\mathrm{i}$ undersøkelsen. Utvalget besto av et hovedutvalg $(\mathrm{N}=5000)$ og et tilleggsutvalg $(\mathrm{N}=5000)$. Mens en for hovedutvalget brukte besøksintervju, brukte en for tilleggsutvalget telefonintervju. Samtlige fikk også et postalt spørreskjema. Hovedutvalget ble trukket fra et sett av geografiske områder, som igjen var gruppert i 109 strata. Tilleggsutvalget ble trukket tilfeldig fra hele landet, uten stratifisering. I den foreliggende undersøkelse, som i den ovenfor (15), inngår bare de som er over 25 år gamle. Dette fordi det er vanskelig å bruke inntekt og utdannelse som mål på sosioøkonomisk status for de som er yngre. Med en frafallprosent på 28,1, inngår 6122 personer (2900 menn og 3222 kvinner) i undersøkelsen. Da ikke alle har svart på alle spørsmål blir det utvalg som inngår $i$ analysen noe mindre, noe avhengig hvilke variable det er tale om.

\section{Variable}

\section{Psykisk helse}

Alle personer i materialet ble tilsendt et postalt spørreskjema med blant annet spørsmål om psykisk helse og bruk av alkohol. Som mål på psykisk helse brukte en Hopkins Symptom Checklist - 25 items (HSCL25), og en valgte det konvensjonelle cut-off point på 1,75 for å angi forekomst av psykiske plager eller lidelser. De øvrige opplysninger ble innhentet ved direkte intervju eller telefonintervu basert på spørreskjema, samt registerdata. Følgende variable inngår i undersøkelsen:

\section{Sosioøkonomisk status}

Inntektsdata er innhentet fra Likningsregisteret, og inntekt er inndelt i 3 grupper etter disponibel inntekt: Lav (25\% laveste inntekt), middels $(50 \%)$ og høy inn- tekt (25\% høyeste inntekt). Utdanningsdata er innhentet fra Utdanningsregisteret, og også utdanning er inndelt i 3 grupper: Lav (inntil 9 års utdanning), middels (fullført videregående skole) og høy utdanning (fullført høyskole, universitets- eller forskerutdannelse)

\section{Sivil status}

Det forelå bare pålitelige data for inndelingen: Gift/ registrert partner, samboende og ikke fast parforhold. Det er således ikke mulig å skille ut tidligere gifte som egen kategori.

Sosial støtte

Her ble det spurt om vedkommende hadde noen fortrolige venner utenom familien, ja eller nei.

\section{Alkoholvaner}

Opplysningene er basert på spørsmålet: Omtrent hvor ofte drakk du noen form for alkohol de siste 12 månedene. Inndeling: 4-7 ganger i uken, 2-3 ganger i uken, omtrent en gang i uken, 2-3 ganger i måneden, omtrent en gang $\mathrm{i}$ måneden, sjeldnere enn en gang i måneden, sjeldnere enn en gang $i$ året/aldri.

\section{Bosted}

Materialet er inndelt etter fylke, landsdel og antall mennesker i kommunen. I vår analyse har vi først inndelt etter antall innbyggere i kommunen (under 200, 200-1999, 2000-19 999, 20 000-99 999, og 100000 og over) Dernest har vi brukt en inndeling som kombinerer landsdel og antall i kommunen. Vi har da valgt å skille ut de fire byer som har en befolkning på over 100000 (Oslo, Bergen, Trondheim og Stavanger) og ellers delt inn i følgende landsdeler: Akershus, Østlandet for øvrig, Hedmark/Oppland, Agder/Rogaland, Vestlandet, Trøndelag og Nord-Norge.

Fordelingen av materialet etter bosted, kjønn og alder fremgår av tabell 1.

Det er liten forskjell i gjennomsnittsalder mellom de ulike områder, og bortsett fra i ett område (Trøndelag), er det en overvekt av kvinner. I de fleste områder er kvinnene litt eldre enn mennene. Alt $i$ alt er forskjellene så små at de neppe kan forklare eventuelle geografiske forskjeller når det gjelder forekomst av psykiske plager.

Tabell 1. Geografisk fordeling etter kjønn og alder.

\begin{tabular}{lccccc}
\hline & \multicolumn{3}{c}{ Antall } & \multicolumn{3}{c}{ Alder (gj.snitt) } & \\
\cline { 2 - 5 } & Menn & Kvinner & Menn & Kvinner & M/K \\
\hline Oslo & 316 & 379 & 49,6 & 49,5 & 0,83 \\
Akershus & 297 & 353 & 49,0 & 48,3 & 0,84 \\
Østlandet ellers & 597 & 615 & 50,1 & 50,1 & 0,97 \\
Hedmark/Oppland & 250 & 268 & 51,2 & 52,8 & 0,93 \\
Agder/Rogaland & 324 & 346 & 48,3 & 50,3 & 0,94 \\
Stavanger & 74 & 75 & 45,8 & 52,0 & 0,99 \\
Vestlandet & 351 & 413 & 47,7 & 49,3 & 0,85 \\
Bergen & 138 & 155 & 48,2 & 48,6 & 0,89 \\
Trøndelag & 189 & 181 & 52,1 & 49,4 & 1,04 \\
Trondheim & 79 & 106 & 46,0 & 47,1 & 0,74 \\
Nord-Norge & 285 & 331 & 48,8 & 49,1 & 0,86 \\
\hline Hele landet & 2900 & 3222 & 49,2 & 49,7 & 0,90 \\
\hline
\end{tabular}




\section{Statistiske metoder}

Alle analysene ble stratifisert på kjønn, og bare de over 24 år ble med i analysene. Det ble benyttet logistisk regresjon og både univariate og multiple regresjonsmodeller ble beregnet. Regresjonsmodellene ble bygget opp ved å legge til en og en variabel. Statistikkpakken SPSS 10.1 ble benyttet til de statistiske analysene.

\section{RESUltater}

Når vi ser på fordelingen av psykiske helseproblemer etter antall personer i kommunen, finner vi svært små forskjeller. For kvinner er det ingen signifikant forskjell, i det hyppigheten av psykiske helseproblemer varierer mellom $12,3 \%$ og $14,0 \%$. For menn skiller imidlertid områder i kategorien "flere enn 100000 bosatte" seg ut med noe større hyppighet av psykiske helseproblemer enn de øvrige. I disse byområdene finnes en hyppighet på 11,1\%, mens hyppigheten av psykiske helseproblemer i de øvrige områder varierer lite og ligger mellom 7,2\% og 8,4\%. Når en kontrollerer for alder $\mathrm{i}$ en logistisk regresjonsanalyse (tabell ikke vist), er det for menn en statistisk signifikant øket hyppighet av psykiske plager for de som bor i gruppen områder med mer enn 100000 innbyggere. Om dette gjelder alle de fire større byer som inngår i gruppen, gir ikke denne analysen svar på.

Fordelingen av psykiske helseproblemer, når en deler inn etter større byer og landsdeler, fremgår av figur 1. Både for kvinner og menn er det ganske stor variasjon i hyppigheten av psykiske plager mellom de ulike områder. Da konfidensintervallene i stor utstrekning er overlappende, kan imidlertid mye av denne variasjon skyldes tilfeldigheter.

For menn er det to områder som skiller seg ut: Oslo med størst $(13,5 \%)$ og Vestlandet med lavest hyppighet $(5,2 \%)$. Denne forskjellen er statistisk signifikant. Også for Trondheim er det lave tall $(5,3 \%)$, men på grunn av det begrensede utvalg fra denne by $(\mathrm{N}=76)$ er muligheten stor for at dette kan skyldes tilfeldigheter.

For kvinner er fordelingen noe annerledes enn for menn, i det Hedmark/Oppland skiller seg ut med størst hyppighet av psykiske plager (18,1\%). Også her kommer Vestlandet godt ut (10,0\%), og forskjellen mellom disse to landsdelene er statistisk signifikant. Oslo og Nord-Norge kommer forholdsvis dårlig ut (henholdsvis $15,5 \%$ og $14,9 \%$ ), mens Bergen kommer gunstigst ut av samtlige områder $(9,3 \%)$.

Når det gjelder den kjønnsvise fordeling av psykiske plager, finnes for alle områder en større hyppighet blant kvinner enn blant menn. En merker seg imidlertid at det synes å være mindre kjønnsforskjell i byene enn i de andre områdene. Spesielt for Oslo, Bergen og Stavanger er forskjellene små, mens Trondheim viser samme mønster som de øvrige områder, med betydelig mer plager blant kvinner enn blant menn.

Den relative betydning av de enkelte områder for den psykiske helse, uttrykt ved Odds ratio (OR), fremgår av tabell 2, som viser resultatene fra en logistisk regresjonsanalyse.

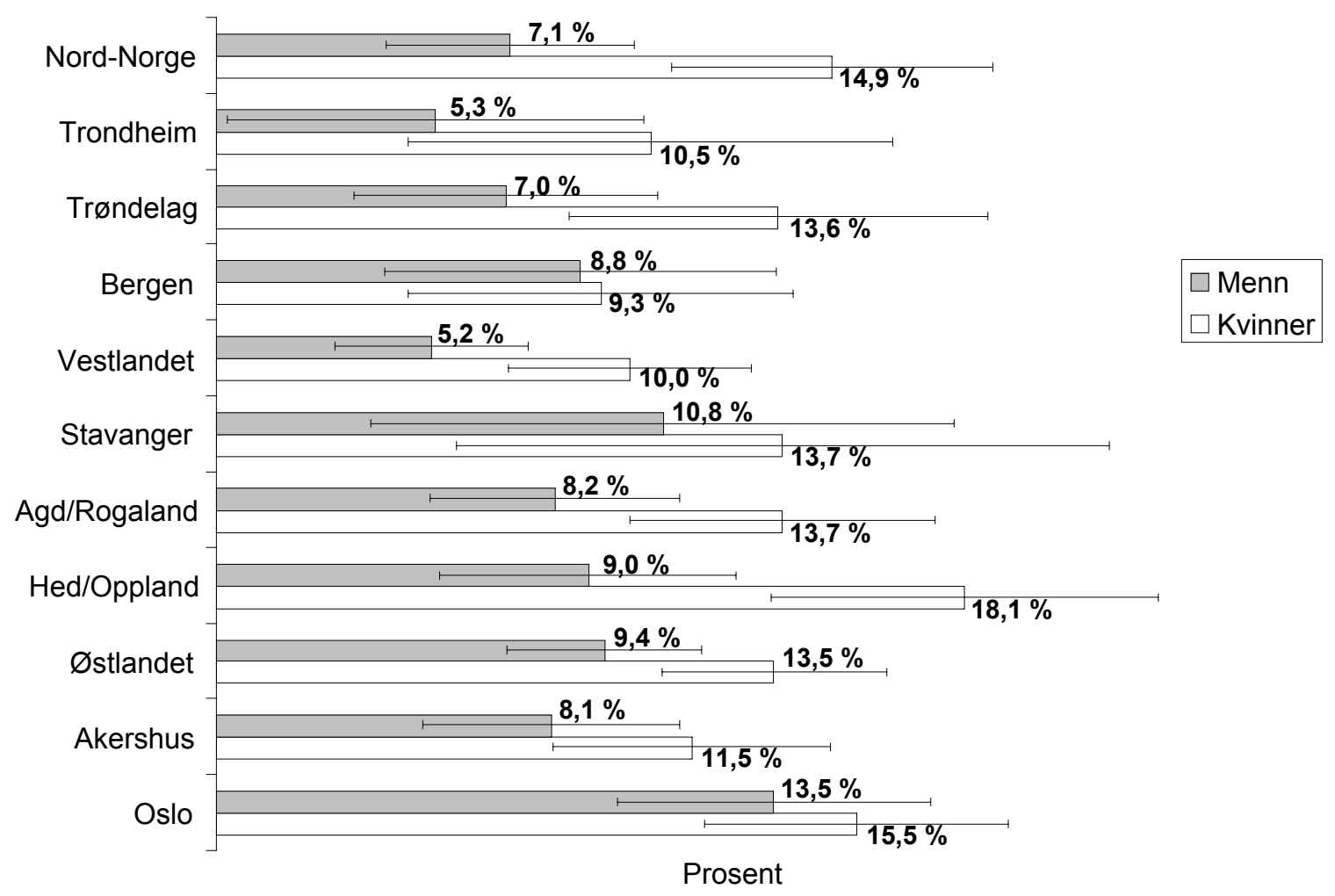

Figur 1. Psykiske helseproblemer (HSCL-25>1,75), menn og kvinner. Med 95\% konfidensintervall. 
Tabell 2. Logistisk regresjon. Avhengig variabel: HSCL$25>1,75$. Uavhengig variabel: Geografisk område.

\begin{tabular}{lcc}
\hline & $\begin{array}{c}\text { Menn } \\
\text { OR }(95 \% \mathrm{CI})\end{array}$ & $\begin{array}{c}\text { Kvinner } \\
\text { OR }(95 \% \mathrm{CI})\end{array}$ \\
\hline Oslo & $2,84(1,60-5,04)^{* * *}$ & $1,66(1,08-2,55)^{*}$ \\
Akershus & $1,60(0,85-3,02)$ & $1,17(0,73-1,85)$ \\
Østlandet & $1,90(1,10-3,29)^{*}$ & $1,40(0,94-2,10)$ \\
Hedmark/Oppl. & $1,81(0,95-3,45)$ & $2,00(1,27-3,14)^{* *}$ \\
Agder/Rogaland & $1,62(0,87-3,01)$ & $1,43(0,91-2,25)$ \\
Stavanger & $2,21(0,92-5,30)$ & $1,43(0,68-3,00)$ \\
Bergen & $1,75(0,82-3,74)$ & $0,93(0,49-1,76)$ \\
Trøndelag & $1,37(0,66-2,87)$ & $1,42(0,83-2,44)$ \\
Trondheim & $1,02(0,33-3,09)$ & $1,05(0,52-2,13)$ \\
Nord-Norge & $1,40(0,73-2,71)$ & $1,57(1,00-2,46)^{*}$ \\
Vestlandet & Referanse & Referanse \\
\hline
\end{tabular}

Signifikansnivå: $* 0,05>\mathrm{p}>0,01 \quad * * 0,01>\mathrm{p}>0.001 \quad * * * 0,001>\mathrm{p}$

For menn peker Oslo seg klart ut, med OR på 2,84, hvilket er signifikant høyere enn i referansepopulasjonen, Vestlandet. Også Østlandet, med OR på 1,90, har en signifikant øket hyppighet av psykiske plager, mens de øvrige områder ikke skiller seg signifikant ut fra referansepopulasjonen.

Når det gjelder kvinner, kommer også Oslo forholdsvis dårlig ut, med OR på 1,66, men her er det Hedmark/Oppland som kommer dårligst ut (OR 2,00). Også Nord-Norge viser en signifikant øket hyppighet av psykiske plager (OR 1,57) sammenliknet med referansepopulasjonen.

Det neste spørsmål er i hvor stor grad de geografiske forskjeller kan forklares gjennom ulik fordeling av sosiodemografiske og psykososiale variable. Som det fremgår av undersøkelsen til Rognerud et al (16), finnes det nemlig en sammenheng mellom flere av disse variable og den psykiske helse. Hos menn slår lav inntekt negativt ut, mens det samme er tilfelle når det gjelder lite utdannelse hos kvinner. For begge kjønn er det å ikke ha minst en fortrolig venn utenfor familien negativt, likeledes det å ikke leve i parforhold. Hos menn er det de som drikker oftest (4-7 ganger pr. uke), og de som aldri drikker, eller drikker mindre enn en gang pr. måned som har mest psykiske plager. På denne bakgrunn er det mulig at den økede hyppighet av psykiske plager i enkelte geografiske områder kan skyldes at det er forholdvis mange med lav inntekt og/eller lite utdannelse her, eller forholdvis mange som ikke lever i parforhold eller som mangler sosial støtte.

La oss først se på hvordan de sosiodemografiske og psykososiale variable fordeler seg på geografiske områder. Den prosentvise fordeling når det gjelder sosiale belastningsfaktorer, dvs. "ikke parforhold", "lav utdanning", "lav inntekt", "ingen fortrolig venn" og "stort alkoholforbruk", slik disse variable er definert ovenfor, fremgår av tabell 3.

Vi skal ikke feste oss ved detaljer her, men bare peke på noen hovedtrekk. Når det gjelder "ikke gifte" skiller Oslo seg klart ut, spesielt når det gjelder kvinner, med flere ikke gifte enn i de andre områder. For kvinner er hele 45,2\% av utvalget fra Oslo ikke gifte (dvs. aldri gifte eller tidligere gifte). Når det gjelder utdannelse, går tendensen i retning av forholdvis få med lite utdannelse i Oslo og Akershus, for mennene også i de andre større byer, mens den største andel med lite utdannelse finnes i Hedmark/Oppland og i Nord-Norge. Når det gjelder inntekt, kommer Oslo og Akershus gunstigst ut blant kvinnene, mens det er vanskeligere å finne noe mønster blant mennene. Med hensyn til venner er det heller ikke lett å finne noe mønster. En merker seg imidlertid at Oslo, som jo har største hyppighet av psykiske plager, kommer gunstig ut når det gjelder venner, mens Vestlandet, med lite psykiske helseproblemer, kommer dårlig ut. Når det gjelder forbruk av alkohol, er det et klart mønster, i det Oslo og de andre større byer har størst andel av folk som drikker alkohol 2-3 ganger i uka eller mer.

Når det gjelder den videre analyse, der flere faktorer trekkes inn samtidig $\mathrm{i}$ en logistisk regresjonsanalyse, har vi slått sammen Bergen, Trondheim og Stavanger til kategorien "Byer" for å få et tilstrekkelig stort antall personer i hvert område. Dette til tross for at disse byene viser noe varierende hyppighet av psykiske helseproblemer (men OR er overlappende, så forskjellene er ikke signifikante).

Tabell 4 viser en serie med logistiske regresjonsanalyser, der en har trukket inn ulike kombinasjoner av de faktorer en ønsker å kontrollere for effekten av.

Tabell 3. Fordeling av risikofaktorer. Prosent.

\begin{tabular}{|c|c|c|c|c|c|}
\hline & $\begin{array}{c}\text { Ikke } \\
\text { gift }\end{array}$ & $\begin{array}{l}\text { Lav ut- } \\
\text { dannelse }\end{array}$ & $\begin{array}{c}\text { Lav } \\
\text { inntekt }\end{array}$ & $\begin{array}{c}\text { Få } \\
\text { venner }\end{array}$ & $\begin{array}{c}\text { Mye } \\
\text { alkohol }\end{array}$ \\
\hline \multicolumn{6}{|l|}{ Menn } \\
\hline Oslo & 29,2 & 11,8 & 15,6 & 14,9 & 27,2 \\
\hline Akershus & 16,2 & 12,5 & 7,5 & 15,8 & 20,5 \\
\hline Østlandet & 15,3 & 18,6 & 14,8 & 17,9 & 15,5 \\
\hline Hedmark/Oppland & 23,5 & 29,8 & 16,5 & 16,8 & 10,2 \\
\hline Agder/Rogaland & 15,8 & 17,7 & 9,3 & 16,0 & 12,0 \\
\hline Stavanger & 21,7 & 14,3 & 11,0 & 23,0 & 25,0 \\
\hline Vestlandet & 19,0 & 19,1 & 11,4 & 21,7 & 12,5 \\
\hline Bergen & 19,5 & 12,8 & 13,9 & 20,3 & 23,9 \\
\hline Trøndelag & 22,1 & 21,8 & 15,9 & 19,6 & 10,2 \\
\hline Trondheim & 22,4 & 16,5 & 7,6 & 19,0 & 26,6 \\
\hline Nord-Norge & 22,8 & 23,8 & 19,4 & 21,8 & 13,6 \\
\hline Totalt & 19,7 & 18,5 & 13,4 & 18,3 & 16,5 \\
\hline \multicolumn{6}{|l|}{ Kvinner } \\
\hline Oslo & 45,2 & 18,6 & 25,3 & 8,7 & 17,3 \\
\hline Akershus & 27,0 & 18,4 & 29,3 & 4,8 & 12,2 \\
\hline Østlandet & 26,7 & 24,8 & 37,4 & 10,9 & 6,4 \\
\hline Hedmark/Oppland & 25,9 & 31,4 & 41,4 & 10,1 & 2,3 \\
\hline Agder/Rogaland & 28,6 & 20,9 & 42,3 & 7,5 & 4,9 \\
\hline Stavanger & 25,8 & 28,0 & 37,3 & 16,0 & 8,2 \\
\hline Vestlandet & 26,7 & 21,9 & 39,6 & 10,7 & 4,5 \\
\hline Bergen & 29,4 & 20,3 & 34,2 & 6,5 & 10,0 \\
\hline Trøndelag & 19,5 & 21,9 & 38,7 & 8,3 & 4,5 \\
\hline Trondheim & 31,2 & 25,5 & 32,1 & 8,5 & 4,8 \\
\hline Nord-Norge & 22,8 & 29,1 & 32,0 & 6,9 & 4,7 \\
\hline Totalt & 28,5 & 23,3 & 35,4 & 8,8 & 7,5 \\
\hline
\end{tabular}


Tabell 4. Logistisk regresjon. Avhengig variabel: HSCL-25>1,75.

\begin{tabular}{lllll}
\hline Kontroll for: & \multicolumn{1}{c}{ Alder } & $\begin{array}{c}\text { Alder og } \\
\text { sivil stand }\end{array}$ & $\begin{array}{c}\text { Alder, inntekt og } \\
\text { utdannelse }\end{array}$ & $\begin{array}{c}\text { Alder, sivil stand, } \\
\text { inntekt og utdannelse }\end{array}$ \\
\hline Menn & & & & \\
Oslo & $2,8(1,6-5,0)^{* * *}$ & $2,3(1,2-4,5)^{*}$ & $3,0(1,6-5,3)^{* * *}$ & $2,5(1,3-4,9)^{* *}$ \\
Akershus & $1,6(0,8-3,0)$ & $1,8(0,9-3,6)$ & $1,9(1,0-3,7)^{*}$ & $2,0(1,0-4,1)^{*}$ \\
Østlandet & $1,9(1,1-3,3)^{*}$ & $1,9(1,0-3,5)^{*}$ & $1,8(1,1-3,2)^{*}$ & $1,9(1,0-3,5)^{*}$ \\
Hedmark/Oppland & $1,8(0,9-3,4)$ & $1,5(0,7-3,2)$ & $1,6(0,8-3,0)$ & $1,5(0,7-3,0)$ \\
Agder/Rogaland & $1,6(0,9-3,0)$ & $1,6(0,8-3,1)$ & $1,6(0,8-3,0)$ & $1,5(0,8-3,1)$ \\
Trøndelag & $1,3(0,6-2,8)$ & $0,9(0,4-2,2)$ & $1,2(0,5-2,5)$ & $0,9(0,4-2,2)$ \\
Nord-Norge & $1,4(0,7-2,7)$ & $1,0(0,5-2,2)$ & $1,2(0,6-2,3)$ & $0,9(0,4-2,0)$ \\
Byer & $1,7(0,9-3,1)$ & $1,7(0,8-3,4)$ & $1,9(1,0-3,5)^{*}$ & $1,8(0,9-3,7)$ \\
Vestlandet & & & & Referanse \\
\hline Kvinner & & & & \\
Oslo & $1,7(1,1-2,5)^{*}$ & $1,8(1,1-3,0)^{*}$ & $1,8(1,2-2,9)^{* *}$ & $2,1(1,3-3,5)^{* *}$ \\
Akershus & $1,2(0,7-1,9)$ & $1,2(0,7-2,1)$ & $1,2(0,8-2,0)$ & $1,3(0,7-2,2)$ \\
Østlandet & $1,4(0,9-2,1)$ & $1,6(1,0-2,5)^{*}$ & $1,4(0,9-2,1)$ & $1,6(1,0-2,5)^{*}$ \\
Hedmark/Oppland & $1,9(1,2-3,1)^{* *}$ & $2,3(1,3-3,7)^{* *}$ & $1,8(1,1-2,8)^{*}$ & $2,2(1,3-3,7)^{* *}$ \\
Agder/Rogaland & $1,4(0,9-2,2)$ & $1,5(0,9-2,5)$ & $1,4(0,9-2,2)$ & $1,5(0,9-2,5)$ \\
Trøndelag & $1,4(0,8-2,4)$ & $1,4(0,8-2,7)$ & $1,4(0,8-2,5)$ & $1,4(0,8-2,7)$ \\
Nord-Norge & $1,6(1,1-2,5)^{*}$ & $1,9(1,2-3,1)^{*}$ & $1,6(1,0-2,5)^{*}$ & $1,9(1,1-3,1)^{*}$ \\
Byer & $1,1(0,7-1,7)$ & $1,2(0,7-2,0)$ & $1,1(0,7-1,8)$ & $1,2(0,7-2,1)$ \\
Vestlandet & & & & Referanse \\
\hline Signifikansnivå:*0,05>p $>0,01 \quad * * 0,01>\mathrm{p}>0,001$ & $* * * 0,001>\mathrm{p}$ & &
\end{tabular}

Som vi tidligere antok, bidrar alder lite til å forklare de geografiske forskjeller når det gjelder psykiske plager, i det OR for de ulike områder er praktisk talt uforandret $\mathrm{i}$ forhold til tabell 2. Når en trekker inn sivil stand, i tillegg til alder, skjer det imidlertid en klar reduksjon av OR for menn i Oslo. For kvinnene er det derimot en tendens til økende OR når det kontrolleres for sivil stand, også i Oslo. Men selv med kontroll for alder og sivil stand, er det stort sett de samme områdene som kommer dårligst ut med hensyn til psykiske plager. Når en tar inn utdannelse og inntekt, i tillegg til alder, merker vi oss spesielt at OR for Oslo stiger både for menn og kvinner. Et tilsvarende forhold gjør seg gjeldende for menn også $\mathrm{i}$ andre byer og Akershus, men for øvrig endrer bildet seg lite. Til sist har en kontrollert for både alder, sivil stand, utdannelse og inntekt. Da går $\mathrm{OR}$ for Oslo noe ned igjen for menn, men viser en gjennomgående stigning for kvinner. Det endelige resultat når en kontrollerer for samtlige variable, blir da følgende: For menn har Oslo, Akershus og Østlandet for øvrig en signifikant større hyppighet av psykiske plager enn Vestlandet, mens det for kvinnene er Oslo, Østlandet for øvrig, Hedmark/ Oppland og Nord-Norge som kommer signifikant dårligere ut enn Vestlandet.

I tillegg til de sosiodemografiske variable har en også kontrollert for effekten av "fortrolig venn" og forbruk av alkohol. Ingen av disse variable bidrar til å forklare forskjellen mellom de ulike geografiske områder når det gjelder psykiske plager (ikke vist $\mathrm{i}$ tabellen).

For å få et klarere bilde av forskjellene mellom områder med stor og lav hyppighet av psykiske plager, og betydningen av de sosiodemografiske variable, har en valgt å se nærmere på forholdet mellom de to ytterpunkter, Oslo og Vestlandet. For å få tilstrekkelig store tall, har en slått sammen menn og kvinner. Når en sammenlikner innen de ulike inntektsgrupper, finnes det hele tiden en betydelig større hyppighet av psykiske plager i Oslo. Det samme er tilfelle for sivil stand. Når en imidlertid ser på utdanning, viser det seg at det blant dem med høy utdanning ikke er noen forskjell med hensyn til psykiske plager mellom Vestlandet og Oslo (8,8\% i Oslo og 8,5\% på Vestlandet). Forholdet er annerledes når det gjelder de med lavest utdannelse. Her kommer de som bor i Oslo klart dårligst ut med 27,3\% mot 11,6\% med psykiske plager på Vestlandet. Dette betyr at det er større forskjell mellom de med høy og lav utdannelse i Oslo enn på Vestlandet når det gjelder psykiske plager, og dette bidrar til å forklare de høye tall for Oslo samlet.

\section{DISKUSJON}

Det er grunn til å tro at undersøkelsen bygger på et materiale som er rimelig representativt for ulike deler av Norge, og at en således kan trekke slutninger om den geografiske fordeling av psykiske plager, målt ved HSCL-25. Data er imidlertid mangelfulle når det gjelder en del sentrale sosiale og psykososiale variable, som flytting, sivil stand og sosial støtte. Dette, i tillegg til at det dreier seg om en tverrsnittsundersøkelse, gjør det vanskelig å trekke slutninger om årsaksforhold. En skal også være varsom med å trekke slutninger om 
forekomsten av psykiatrisk sykdom, eller psykiske lidelser av alvorligere grad, da det anvendte måleinstrument, HSCL-25, ikke er en målemetode for psykiatriske diagnoser, men for grad av plagsomme symptomer på hovedsakelig angst og depresjon.

Et sentralt funn i undersøkelsen er den relativt store hyppighet av psykiske plager i Oslo, både hos menn og kvinner. Dette kan muligens henge sammen med de til dels dramatiske forskjeller innen Oslo når det gjelder psykisk helse som er beskrevet i andre undersøkelser. I Oslo finnes både de beste og de dårligste områder $\mathrm{i}$ landet, og dette gjelder ikke bare psykisk helse, men også levekår og somatisk helse, målt ved gjennomsnittlig levetid (SSB 2002). Dette at den relativt store hyppighet av psykiske og andre helseplager i Oslo i betydelig grad kan knyttes til enkelte sosialt depriverte bydeler, kan tyde på at det snarere er de sosiale ulikheter innen Oslo, og ikke det gjennomsnittlige sosioøkonomiske nivå, som forklarer de høye tall for psykiske plager. Dette ville i så fall være i samsvar med Dohrenwends funn, som jo nettopp gikk i retning av at de høye tall for psykiske lidelser i byene var knyttet til store sosiale ulikheter, og at det særlig var de med lav sosioøkonomisk status i byene som hadde en øket psykiatrisk morbiditet. Dette passer også med det vi fant i sammenlikningen mellom Oslo og Vestlandet, der det bare var de med lite utdannelse i Oslo som hadde en markert øket hyppighet av psykiske plager.

Hvis det er slik at den relativt store hyppighet av psykiske plager i storbyen henger sammen med store sosiale ulikheter, har vi fortsatt et forklaringsproblem. En mulighet er at ulikhetene fører til øket relativ deprivasjon og øket stress hos de som er nederst på den sosiale rangstige, og som står frem som tapere i storbyens harde konkurransesamfunn. En annen mulighet er imidlertid at storbyen har en tendens til å trekke til seg folk som har dårlig psykisk helse før de kommer til byen, f.eks. knyttet til stoff- eller alkoholmisbruk, og at de sosiale ulikheter er et resultat av selektiv flytting. Det er også en mulighet at et forholdsvis stort antall fremmedkulturelle innvandrere i Oslo kan bidra til den økede hyppighet av psykiske helseproblemer. Da det ikke finnes opplysninger om fødested eller flytninger i det foreliggende materiale, kan ikke denne undersøkelsen gi noe svar på dette. Det er imidlertid tankevekkende at Astrup og Ødegård i en migrasjonsundersøkelse basert på sykehusinnleggelser fant at nettopp de som flyttet til Oslo hadde en øket hyppighet av psykoser (17). En tredje mulighet er at den relativt store hyppighet av psykiske plager i Oslo henger sammen med en ukjent storbyfaktor, og at den store hyppighet av psykiske plager hos de med lite utdannelse $\mathrm{i}$
Oslo kan forklares ved seleksjon.

Hvorfor en finner til dels betydelige forskjeller i psykisk helse mellom de lite urbaniserte områder i materialet, kan ikke undersøkelsen gi noe svar på. Selv om vi for eksempel har noen enkle data om sosialt nettverk, er dette på ingen måte tilstrekkelig til å si noe om graden av sosial integrasjon i de ulike områder, som jo i andre undersøkelser har fremstått som en forklaringsfaktor. En fester seg imidlertid ved at det for kvinnene finnes en relativt stor hyppighet av psykiske plager i de områder som har det laveste nivå når det gjelder utdanning, nemlig Hedmark/Oppland og NordNorge. Selv om forskjellene ikke forsvinner når en kontrollerer statistisk for utdanning, er det likevel mulig at det relativt lave utdanningsnivå indikerer mer dyptgripende sosiale problemer som de anvendte målemetoder ikke fanger opp.

Når det gjelder de spesielt gunstige tall for Vestlandet med hensyn til psykiske plager, er dette i samsvar med Kringlens og medarbeideres mer grundige undersøkelse, og det er også interessant at Dahl for 150 år siden fant at nettopp Vestlandet kom gunstigst ut når det gjelder alvorlige sinnslidelser. Selv om det er forskjell på psykiske plager og sinnssykdom, er likheten $\mathrm{i}$ funn tankevekkende. Når dertil Vestlandet har den laveste mortalitet av samtlige geografiske områder $\mathrm{i}$ Norge (18), kan en saktens lure på om det finnes en egen "Vestlandsfaktor" med forankring både i biologi, kultur og livsstil.

\section{KONKLUSJON}

Som det fremgår av både denne og den foregående artikkel (15), kan Helseundersøkelsen fra 1998 brukes til å fremskaffe interessante resultater, både fra et teoretisk og praktisk synspunkt, når det gjelder befolkningens psykiske helse. På en del områder er imidlertid de innsamlede data mangelfulle, slik at det er vanskelig å trekke slutninger om sammenhengen mellom psykisk helse og de sosiodemografiske variable. Det er for eksempel behov for flere psykososiale data, som sosial støtte, sosial deltakelse, selvfølelse og mestring, som kan bidra til å forklare hvorfor enkelte sosiale grupper har dårligere psykisk helse enn andre. I samsvar med dette arbeides det nå med å få inn flere data av denne type i det som skal bli 3-årige Helse- og Levekårsundersøkelser i regi av Statistisk Sentralbyrå, hvorav den første er planlagt allerede til høsten 2002. Dette arbeid skjer i kontakt med tilsvarende arbeid i andre Europeiske land, slik at en kan få et bedre grunnlag for internasjonale sammenlikninger.

\section{REFERANSER}

1. Dahl L. Bidrag til Kundskap om de Sindssyge i Norge. Christiania: Den Steenske Bogtrykkeri, 1859.

2. Sandanger I, Nygård JF, Ingebrigtsen G, Sørensen T, Dalgard OS. Prevalence, incidence rate and age at onset of psychiatric disorders in Norway. Soc Psychiatry Psychiatr Epidemiol 1999; 34: 570-579. 
3. Grøtvedt L, et al. Helseprofil for Oslo. Nasjonalt Folkehelseinstitutt, 2002.

4. Kringlen E, Torgersen S, Cramer VA. Norwegian psychiatric epidemiological study. Am J Psychiatry 2001; 158: 1091-1098.

5. Kringlen E (2002). Personlig meddelelse.

6. Ayuso-Mateos JL, Vazquez-Barquero JL, Dowrick C, Lehtinen V, Dalgard OS, Casey P, Wilkinson C, Lasa L, Page H, Dunn G, Wilkinson G, the ODIN group. Depressive disorders in Europe: prevalence figures from the ODIN study. Br J Psychiatry 2001; 179: 308-316.

7. Lavik NJ. Ungdoms mentale helse. Oslo: Universitetsforlaget, 1976.

8. Dalgard OS, Brevik JI, Hjemmen A. Helseprofil i lokalsamfunnet, med særlig vekt på sosiale risikofaktorer og psykisk helse. I: Dalgard, Døhlie, Ystgaard, red. Sosialt nettverk, helse og samfunn. Oslo: Universitetsforlaget, 1995: 126-143.

9. Dalgard OS. Community health profile: A tool for psychiatric prevention. In: Trent DR, Reeds C, eds. Promotion of Mental Health, Vol 5. Aldershot: Avebury, 1996.

10. Sørensen T. Nordkyst-prosjektet. Mental helse i Nordkyst. Fylkeshelsesjefen, Nordland Fylkeskommune, 1987.

11. Sørensen T. Pendling, lokalmiljø og psykisk helse (doktoravhandling). Psykiatrisk Institutt, Universitetet i Oslo, 1979.

12. Dalgard OS. Bomiljø og psykisk helse. Oslo: Universitetsforlaget, 1980.

13. Dohrenwend BP, Dohrenwend BS. Psychiatric disorders in urban settings. In: Caplan G, ed. American Handbook of Psychiatry, Rev. Edn., Vol. 3. New York: Basic Books, 1972.

14. Leighton AH, et al. My Name is Legion. New York: Basic Books, 1959.

15. Faris REL, Dunham HW. Mental Disorders in Urban Areas. Chicago: University of Chicago Press, 1939.

16. Rognerud M, Strand BH, Dalgard OS. Psykisk helse i Helse- og levekårsundersøkelsen i 1998. I. Sosioøkonomiske forskjeller i psykisk helse og livsstil. Norsk Epidemiologi 2002; 12 (3): 239-248.

17. Astrup C, Ødegård Ø. Internal migration and mental disease in Norway. Psychiat Q, 1960; Suppl 34: 116130.

18. Statistisk Sentralbyrå. Befolkningsstatistikk 2000. 